\title{
Team Based Learning in Speech, Language and Hearing Sciences: experience in the Public Health qualification
}

\author{
Edinalva Neves Nascimento ${ }^{1}$ \\ https://orcid.org/0000-0002-8154-0716 \\ Gabriela Maria de Oliveira Moreira ${ }^{1}$ \\ https://orcid.org/0000-0002-0269-8794 \\ Keylla Geovanna Laureano Tolentino ${ }^{1}$ \\ https://orcid.org/0000-0003-4880-5580 \\ Ana Cláudia Figueiredo Frizzo ${ }^{1}$ \\ https://orcid.org/0000-0002-7934-4353
}

Universidade Estadual Paulista "Júlio de Mesquita Filho", Marilia, São Paulo, Brasil.

Conflict of interests: Nonexistent

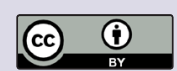

Received on: November 3, 2018 Approved on: April 18, 2019

Corresponding address:

Edinalva Neves Nascimento

Rua Santa Helena, 1967 casa 27, Jardim

Estoril

CEP. 17514-410 - Marília, São Paulo,

Brasil

E-mail: ediquata@gmail.com

\section{ABSTRACT}

Purpose: to present an experience report about Team-Based Learning utilization as an active methodology of learning in a Speech, Language and Hearing Sciences graduation course.

Methods: students enrolled in the public health II subject in the graduation course received the material about breastfeeding by e-mail in advance and were informed about how the activity using Team-Based Learning would be developed. In class, they initially answered to a questionnaire, individually, which was later discussed in teams formed, randomly, by the professor. The answers were placed in charts, to compare individual and teams performances.

Results: 25 female students participated in this study, with ages varying from 18 to 25 years, and differences were found between the individual and the team answers, since the answers chosen by the teams corresponded more to the template elaborated by the teacher. The percentage of correct individual answers was $69,6 \%$ and the percentage of correct team answers was $96 \%$.

Conclusion: the Team-Based Learning utilization showed to be viable from a pedagogical perspective, promoted greater engagement by the students and contributed in the development of teamwork.

Keywords: Speech, Language and Hearing Sciences; Education; Learning 


\section{INTRODUCTION}

Mostly, the institutions that train professionals in the area of health, including Language and Hearing Sciences, organize their formation according to the Flexnerian Model, characterized by the organization of the contents in disciplines and by placing the professor as the central figure in the process of learning. A consequence of this model is the separation of the theoretical and practical contents, as well as the formation of professionals with a good theoretical basis, but struggling in dealing with the wide situations of their area of performance ${ }^{1}$. Aiming at the formation of more and more qualified professionals who address the needs of the labor market and the fulfilling of the curricular guidelines, the teaching institutions are forced to re-evaluate the methods used. In this context, the active learning methodologies gain space, among them, the Team-Based Learning (TBL).

TBL is a methodology developed based on constructivism, which values the previous experiences and knowledge of students, the dialog and interaction among them. This methodology is centered in the student, being the professor a facilitator in the learning process. It is divided in three stages: Individual Preparation (pre-class); Readiness Assurance Test (RAT); and Application of Knowledge (Concepts). The evaluation of students is done both by individual and collective performance ${ }^{2}$. TBL was applied in health courses even in the 1990s and positive aspects were verified, such as, for instance, motivation and engagement of students during the classes, development of communicative skills for teamwork and critical reasoning ${ }^{3}$.

This Active Methodology promotes teamwork, reasoning, communication and argumentation, which are aspects needed for the formation of speech therapists and, besides, it attends the Curricular Guidelines of the Language and Hearing Sciences Courses. According to the Resolution CNE/CES 5, of February 19, 2002, Art. $9^{\text {th, }}$ the undergraduate courses of Language and Hearing Sciences must "have a pedagogical project, collectively built, centered in the student as subject of learning and supported on the professor as facilitator and mediator in the teaching and learning process"4.

However, there are no reports of the application of TBL in Undergraduate Courses of Language and Hearing Sciences, especially in the Discipline of Public Health.
The aim of this article is to present an experience report about the use of TBL as an active methodology of learning in the discipline of Public Health II in an Undergraduate Course in Language and Hearing Sciences.

\section{METHODS}

This study is part of a bigger Project approved by the Committee of Ethics in Research (CEP) of the College of Philosophy and Sciences of the Paulista State University "Júlio de Mesquita Filho", Marilia Campus, under the approval number 2,297,552. It is an experience report of a teaching/learning practice experimented by a professor in an Undergraduate Course in Language and Hearing Sciences. This experience was held specifically in the discipline of Public Health II (30 lesson hours) and used 4 lesson hours of the discipline mentioned on a single day.

There were 30 students enrolled in the discipline, however five of them were absent in the day when the activity was held. Thus, 25 students, at ages between 18 and 25, participated in the TBL, in the morning time. The theme of "Breastfeeding" (anatomy, physiology, and benefits, among others) because it was part of the program content of this discipline.

The stages of TBL were followed. The professor prepared a questionnaire (Attachment) with five multiple-choice questions and each question had five possibilities of answers (A, B, C, D, E) with only one correct answer. In the preparation stage, the students had access to the theoretic materials about breastfeeding, sent by electronic message by the professor responsible for the discipline one week in advance (pre-class).

After one week of the pre-class stage, the students answered to the questionnaire in the class, individually, and registered their answers on the specific tool. After that, the professor read each question and their alternatives. The students raised their hand at the moment when the professor mentioned the alternative they considered to be correct. At this moment, the professor did not present any explanation, in order not to interfere in the team work that would be held afterwards.

Then, the students were divided in six groups, randomly chosen, five of them being composed of four students and one of them of five. The groups discussed about the questions collectively and registered their answers on a second tool, that is, the one for team work. The professor read each question and their alternatives. At the end of each question, she asked the 
teams which one was the correct alternative. Each team raised their sign (made of a bond sheet of paper A4) with the alternative $(A, B, C, D, E)$ the group considered to be correct.

At the stage of application of TBL concepts, the teams could argue about the answers they chose, both in the individual moment and in the collective moment. At this point, the professor elicited from the groups what information was incorrect in the alternatives, bringing up to reflection the theoretic contents available for reading in advance. At the end, the students could evaluate the activity, comparing their individual performance to their collective performance, sharing their opinions about the development of the pedagogical action.

\section{RESULTS}

Table 1. Individual answers of students concerning the questions about breastfeeding in the discipline of Public Health II (N=25)

\begin{tabular}{cccccc}
\hline \multirow{2}{*}{ Question } & \multicolumn{5}{c}{ Individual Answers } \\
\cline { 2 - 6 } & A & B & C & D & E \\
\hline 1 & 3 & 6 & & 1 & 15 \\
2 & 3 & 21 & & 22 & 1 \\
3 & 2 & & 9 & 2 & 1 \\
4 & 2 & 1 & 18 & & 4 \\
5 & & 3 & & & 4 \\
\hline
\end{tabular}

Table 2. Team answers of students concerning the questions about breastfeeding in the discipline of Public Health $\|(N=25$, divided into five groups of four students and one group of five students)

\begin{tabular}{cccccc}
\hline \multirow{2}{*}{ Question } & A & Teams Answers & D & E \\
\cline { 2 - 5 } & & C & & 25 \\
2 & 25 & & 25 & \\
3 & & & 5 & 20 \\
4 & & 25 & & \\
5 & & & & & \\
\hline
\end{tabular}

Template: $1-\mathrm{E} \quad$ 2- B $\quad 3-\mathrm{D} \quad$ 4- E $\quad$ 5- C

We realized that there was difference between the individual answers and the team answers, as it is shown in the Tables 1 and 2. The individual answers showed $69.6 \%$ of hits when all the questions are analyzed, being $60 \%$ of hits in question $1,84 \%$ of hits in question $2,88 \%$ of hits in question $3,44 \%$ of hits in question 4 , and $72 \%$ of hits in question 5 . On the other hand, in team answers, the percentage of hits increased to $96 \%$, with $100 \%$ of hits in questions 1, 2, 3 and 5 , and $80 \%$ of hits in question 4. The teams' answers corresponded more to the template elaborated by the professor. Among the five questions, the teams chose four whose answers coincided to the template. In question 4 there was a divergence in a team; however, the analysis of the question by the groups allowed us to identify that the elaboration of the alternative caused confusion in its interpretation, and it demanded from the professor the reformulation of it, in order to apply the strategy again. That same question showed more discrepancy in individual answers and the least number of hits in both individual and collective answers.

The use of TBL as an active methodology of learning allowed a more active participation of the undergraduate students in Language and Hearing Sciences in building knowledge about breastfeeding. They manifested their answers, reflected individually and collectively, argued about their choices among the existing alternatives and consulted the theoretic material about the theme they were studying.

Besides, it allowed that, in the discipline of Public Health, a critical, reflexive and participative pedagogical practice was developed, or rather, the undergraduate students were protagonists and the professor was 
a mediator of learning, something different from the pedagogical practice of exposition of content.

In team work, according to the feedback of the students themselves, it was possible to realize that they practiced listening and critical argumentation supported by previous reading, and not in common sense anymore, leading them to yield or defend their individual answers, thus promoting group consensus. This result was also noticed by the professor during the discussion of the template, because all the groups were engaged in the debate, especially about question 4 , which caused more disagreement among the teams.

\section{DISCUSSION}

It is said in the Curricular Guidelines of the Courses of Language and Hearing Sciences that the formation of the speech therapist must attend the current health system, which in Brazil is the Unified Health System (SUS). SUS has as its fundamental principles the integrality, which results in the need of team work ${ }^{4}$. As it was already explained, TBL is a methodology which values dialog, as well as it promotes the development of communicative and argumentative skills needed for team work ${ }^{2,3}$.

The importance of team work as a way to achieve integrality is seen in all the levels of health care. It is also noticed that team work is the model used for acting in rehabilitation, because it fosters interdisciplinarity, as well as multidisciplinarity ${ }^{5,6}$. Team work requires well developed communicative skills, because it causes the other individual's listening, as well as interaction and dialog among the ones involved in the process of health care ${ }^{6,7}$.

Besides, studies held which compare the traditional passive methodologies and learning based on teams in Medicine courses show that TBL results in better performances and more satisfaction from students, as well as more engagement and participation of students in the conduction of activities ${ }^{8-11}$. Another study held in 2016 indicated that the application of TBL results in good gains concerning contents and concepts taught in short term, however such gains are not kept in long term ${ }^{12}$.

Since TBL is not the current methodology, it faces some obstacles in its application, which go beyond the preparation of materials for the conduction of the activity, such as, for instance, its implementation, which should be gradual ${ }^{13}$, and the scarcity of studies in the area of Language and Hearing Sciences about the theme.
Therefore, TBL may be an extremely important tool for the qualification of Language and Hearing Sciences professionals, because it prioritizes team work, communicative and argumentative skills, components which are needed for working with SUS and in the labor market, besides resulting in a better academic performance and engagement during their qualification.

\section{FINAL CONSIDERATIONS}

The use of TBL as an active methodology of learning in Language and Hearing Sciences course was shown as viable from the pedagogical point of view, and it was accepted by the students involved, making them more active in the learning process and contributing for the development of communicative and argumentative skills and team work.

Surely, this practice provide students with an opportunity of experiencing a competence that will be fundamental to the multiprofessional work, overcoming the major models existing and fulfilling what is preconized in the Curricular Guidelines of the Language and Hearing Sciences Course. Thus, this practice might be used in other disciplines of the Undergraduate Course and even the Graduate course in Language and Hearing Sciences and related areas.

\section{REFERENCES}

1. Gomes MPC, Ribeiro VMB, Monteiro DM, Leher EMT, Louzada RCR. O uso de metodologias ativas no ensino de graduação nas ciências sociais e da saúde: avaliação dos estudantes. Ciênc. educ. 2010;16(1):181-98.

2. Bollela VR, Senger MH, Tourinho FSV, Amaral E. Aprendizagem baseada em equipes: da teoria à prática. Medicina. 2014;47(3):293-300.

3. Krug RR, Vieira MSM, Maciel MVA, Erdmann TR, Vieira FCF, Koch MC et al. O "Bê-Á-Bá" da aprendizagem baseada em equipe. Rev. bras. educ. méd. 2016;40(4):602-10.

4. Brasil. Ministério da Educação. Diretrizes Curriculares Nacionais para os Cursos de Graduação em Fisioterapia, Fonoaudiologia e Terapia Ocupacional. Parecer CES/CNE 1.210/2001, homologação publicada no DOU 10/12/2001, Seção 1, p. 22. Resolução CES/CNE 04/2002, publicada no DOU 04/03/2002, Seção 1, p. 11. Resolução CES/CNE 05; 06/2002, publicada no DOU 04/03/2002, Seção 1, p. 12. 
5. Uchôa AC, Vieira RMV, Rocha PM, Rocha NSD, Maroto RM. Trabalho em equipe no contexto da reabilitação infantil. Physis. 2012;22(1):385-400.

6. Araújo MBS, Rocha PM. Trabalho em equipe: um desafio para a consolidação da estratégia de saúde da família. Ciênc. saúde coletiva. 2007;12(2):455-64.

7. Araújo MBS, Rocha PM. Saúde da família: mudando práticas? Estudo de caso no município de Natal (RN). Ciênc. saúde coletiva. 2009;14(Supl. 1):1439-52.

8. Jafari Z. A comparison of conventional lecture and team-based learning methods in terms of student learning and teaching satisfaction. Med $\mathrm{J}$ Islam Repub Iran. 2014;28:5.

9. Haidet $\mathrm{P}$, Morgan RO, O'Malley K, Moran BJ, Richards BF. A controlled trial of active versus passive learning strategies in a large group setting. Adv Health Sci Educ Theory Pract. 2004;9(1):15-27.

10. Tai BC, Koh WP. Does team learning motivate students' engagement in an evidencebased medicine course? Ann Acad Med Singap. 2008;37(12):1019-23.

11. Doshi NP. Effectiveness of team-based learning methodology in teaching transfusion medicine to medical undergraduates in third semester: a comparative study. Asian J. Transfus. Sci. 2017;11(2):87-94.

12. Emke AR, Butler AC, Larsen DP. Effects of Team-Based Learning on short-term and long-term retention of factual knowledge. Med Teach. 2016;38(3):306-11 .

13. Oliveira T, Araujo I, Veit E. Aprendizagem Baseada em Equipes (Team-Based Learning): um método ativo para o ensino de física. Cad. Bras. Ens. Fís. 2016;33(3):962-86. 


\section{ATTACHMENT. QUESTIONNAIRE}

\section{1- Point out the correct answer:}

A) The sucking of the nipple will determine an adequate handle for the liberation of prolactin and oxytocin by the pituitary.

B) Colostrum is a mammal secretion available on the first days after birth, rich in proteins, maternal antibodies and fat which will make babies gain weight.

C) At the end of pregnancy, the alveolar development becomes more evident and the secretion of ripe milk begins.

D) "Apojadura" is the drop of milk. The breasts become engorged, sore and there is an increase in temperature. It is common that this situation remains for the first six months of the baby's life.

\section{2- Concerning the hormones that influence breastfeeding:}

A) Prolactin is more secreted during the day, it inhibits ovulation, retarding the return of fertility and menstruation, which protects the mother against a new pregnancy.

B) Prolactin is a hormone that stimulates the alveoli to produce milk.

C) In order to maintain high levels of prolactin, the baby must have a good handle, receive artificial nipples and be breastfed every 24 hours.

D) Oxytocin is a hormone responsible for the drop of milk and makes the uterus be eliminated.

E) In the first days, the mother may feel the contraction of the uterus while breastfeeding, promoting a second childbirth. Some factors which may inhibit the reflection of oxytocin is worry, fear, pain, shame, anxiety.

\section{3- Concerning the definitions of exclusive breastfeeding:}

A) When the child receives mother's milk directly from the breast or milked, regardless of receiving other foods or not, in the first six months.

B) When a child receives mother's milk and other kinds of milk in the first six months.

C) When a child receives, besides mother's milk, any other complementary food, solid or semi-solid, in the first four months.

D) When the child receives only mother's milk directly from the breast or milked, without liquids or other solids, except syrups, vitamins or medicine, in the first 180 days.

E) When the child receives, besides mother's milk, water or other drinks based on water in the first 180 days.

\section{4- Concerning mother's milk:}

A) Mother's milk is strong and adequate for the baby, who will not need another kind of food until its six months of age. After that, it must cease.

B) Milk can be strong or weak, depending much on the mother's biotype and the kind of work she performs.

C) Mothers who work can collect their milk, keep it, and give it to the baby in a bottle when it is hungry.

D) Mothers who produce much milk must empty their breasts during shower and let the milk flow down the drain.

E) The child's father must be close to the mother who breastfeeds, offering physical and emotional help when necessary.

\section{5- Still concerning mother's milk:}

A) Mother's milk is harder to digest than cow milk, and that explains why children wake up more often.

B) In order to avoid cracks, mothers should use moisturizing creams, soap and special lotions on the areola and nipples.

C) Breastfeeding reduces the chances of the mother having breast and ovary cancer.

D) Mothers should be careful in order to avoid that the baby burps on the breast, the milk drops on the floor, breastfeeding while menstruated, because all these things may interfere in the amount and quality of the milk.

E) Mothers who breastfeed should double their eating, because they need to eat for themselves and for the baby. 